\title{
Claude Lefort: Democracia e Luta Por Direitos ${ }^{1}$
}

\author{
Silvana de Souza Ramos ${ }^{2}$
}

\begin{abstract}
RESUMO: Tendo como eixo organizador o debate acerca da noçáo de direitos do homem e do cidadão e a eficácia destes no que se refere à luta política por novos direitos, o artigo investiga o caráter inovador da democracia moderna. Em sua abordagem do tema, C. Lefort combate três teses: a de que a defesa de direitos humanos universais representaria um perigo à política vigorosa, instituída em Estados benevolentes; a de que esses direitos seriam a expressão mais acabada da ideologia do individualismo burguês e corresponderiam a formalidades vazias, cujo sentido seria apenas o de escamotear a violência social e sacralizar privilégios; e, por fim, a tese segundo a qual as instituiçóes democráticas visariam somente a reproduzir as relaçóes de propriedade e força vigentes no capitalismo e não permitiriam que as contradiçôes sociais fossem expressas ou mesmo resolvidas no campo da política. Trata-se de retomar a filosofia política proposta por C. Lefort, a qual enfatiza o caráter inédito da democracia moderna, para entấo explicitar, contrariando tais críticas, a perspectiva histórica de luta por direitos aberta pela invenção democrática.
\end{abstract}

PALAVRAS-CHAVE: Claude Lefort. Karl Marx. Edmund Burke. Democracia. Direitos. Política.

\section{A visáo CRítica SObre OS Direitos UNIVERSAIS}

As primeiras críticas aos direitos do homem e do cidadão não tardaram a aparecer no campo das discussóes políticas e jurídicas. Elas vieram tanto da direita - pela argumentaçáo inaugural de E. Burke - quanto da esquerda - sob a pena revolucionária do jovem $\mathrm{K}$. Marx. Os dois pensadores acusaram de pura abstração a ideia de um homem natural capaz de reivindicar direitos universais. Para E. Burke e K. Marx, tal como apresentado nas declaraçôes dos direitos do homem e do cidadão, o sujeito simplesmente não existe, pois, ou ele é demasiado abstrato para ser real, ou concreto demais para ser universal. É importante retomar os traços definidores dessas duas críticas, pois elas forneceram o horizonte a partir do qual são discutidos até hoje tanto o fundamento jurídico quanto a eficácia política das declaraçóes de direitos feitas no contexto das chamadas revoluçóes modernas do século XVIII. Mas isso não basta. Conforme as teses defendidas por C. Lefort, as quais pretendem responder às críticas mencionadas

\footnotetext{
${ }^{1}$ http://dx.doi.org/10.1590/S0101-317320160002000011

2 Professora do Departamento de Filosofia da Universidade de São Paulo. São Paulo. E-mail: ramos_ si@hotmail.com
} 
acima, precisamos compreender, ainda, o que a experiência histórica posterior às declaraçôes permite revelar acerca da importância destas, não só no que diz respeito à abstração ou concretude dos direitos ali referidos, mas também no que concerne à ligação destes com o surgimento da democracia moderna. Tendo como horizonte essa perspectiva histórica, por meio da avaliação das críticas iniciadas por E. Burke e K. Marx, poderemos encontrar um liame fecundo entre a proclamação dos direitos humanos e o surgimento da democracia moderna enquanto acontecimento inédito, uma vez que ela redefiniu, segundo C. Lefort, as relaçôes entre direito e poder.

\subsection{As CRÍticas de E. BuRKE}

A primeira crítica à teoria dos direitos humanos, publicada por E. Burke, em 1790 - na obra Reflexóes da Filosofia em França - elabora três frentes de ataque à noção de direitos humanos. Em primeiro lugar, E. Burke afirma que o discurso dos direitos padece de idealismo e de racionalismo metafísico. Esse discurso parte da crença de que a prática política deve ser guiada pela teoria, sem se dar conta de que a política enquanto arte do possível nada tem a ver com abstrações teóricas. A especulação teórica visa ao universal e o imutável, ao passo que a prática lida com o particular e o contingente. Essa diferença exige que consideremos o tipo de juízo envolvido em cada uma dessas dimensôes: os juízos políticos ou práticos envolvem casos concretos e não podem esperar, já que precisam responder a pressôes sociais às quais devemos dar uma resposta rápida; os juízos teóricos são dissociados dessas pressóes e, por isso, imparciais: eles partem de um princípio e seguem o caminho necessário à produção de um sistema. Por consequência, o ponto de vista do absoluto cega o político diante de realidades particulares - envolvidas pela contingência e situadas num contexto determinado - e faz desse pretenso ator uma espécie de profeta metafísico.

As constituiçôes elaboradas nesse estado de cegueira são geométricas, o que as torna impotentes para fornecer ao político a virtude da prudência, única capaz de ajudá-lo a de fato computar e equilibrar decisôes no interior dos compromissos firmados em sociedade. Em segundo lugar, o racionalismo dos discursos dos direitos é elaborado de forma tão abstrata e geral, a ponto de torná-lo irreal e irrealizável: Burke "[...] questionava menos os direitos do que a sabedoria de exercitar esses direitos [...] ele tentava restaurar o genuinamente político em vez de uma abordagem legalista” (STRAUSS, 1965, p. 303). A 
natureza abstrata do sujeito dos direitos - o homem desprovido de quaisquer determinações - não é apenas inexistente, pois seu pálido contorno impede que, a partir dele, direitos possam realmente ser exigidos e protegidos. $\mathrm{O}$ único direito eficaz é aquele criado historicamente no interior de tradições e culturas particulares. A humanidade dos direitos universais é apenas imaginária, e a irrealidade ontológica do homem abstrato vinculado a esses direitos conduz inexoravelmente à sua pouca utilidade. Por fim, em terceiro lugar, o racionalismo e a abstração dos direitos os transformam em princípios morais absolutos, igualmente aplicáveis, seja contra governos antigos e benevolentes, seja contra a mais violenta tirania, configurando-se aí um grande perigo. Para E. Burke, as constituiçôes que crescem organicamente são muito melhores do que as que são feitas por um legislador: só o tempo e a injunção de variados acidentes podem dar maturidade a uma constituição. A ordem social deve se desenvolver naturalmente, a fim de permitir o livre florescimento da individualidade. Por consequência, o que a declaraçáo reivindica abstratamente só pode ser conquistado no interior de sociedades maduras, em cujo seio a individualidade possa gozar do tempo exigido para seu desenvolvimento concreto.

A conclusão de Burke não esconde o aspecto conservador de sua abordagem dos direitos. A novidade da Declaração tem ou um caráter inútil, à medida que desconhece a especificidade do político em relação ao teórico, ou um teor perigoso, pois pode colocar em risco a ordem instituída em Estados benevolentes. A defesa das constituiçôes orgânicas - da inglesa, em especial - contra o perigo do direito abstrato aparece como uma defesa da política vigorosa e concreta.

\subsection{As CRÍticas de K. MarX}

Ora, se o que move a argumentação de E. Burke é o temor de que Estados benevolentes sejam ameaçados por novidades abstratas, as preocupaçóes de Marx nos encaminham para outra direção, qual seja, a compreensão dos direitos universais enquanto instância ideológica de dominação de classes. Trata-se de mostrar que o sujeito das declaraçôes não é o homem realmente emancipado e que a liberdade ali promulgada não passa de ilusão política, pois, na verdade, os direitos humanos universais apenas mascaram o egoísmo inerente ao modo de vida burguês. 
No ensaio de juventude, Sobre a questão judaica (1843), o filósofo parte da discussão sobre a emancipação política dos judeus na Alemanha, diante da argumentação polêmica de B. Bauer, que acabaria por rejeitar a reivindicação política da comunidade judaica, por considerá-la mera exigência de um privilégio. Segundo B. Bauer, os judeus reivindicam o direito ao reconhecimento de sua religião, no interior do Estado cristão. Porém, essa demanda seria absurda, à medida que um movimento emancipatório mais efetivo levaria náo ao mero reconhecimento de uma religiáo particular pelo Estado, mas sim à emancipação política de todos os homens no interior desse Estado, independentemente de sua crença. B. Bauer tem em vista, é evidente, os avanços que as revoluçóes modernas da França e dos EUA instauraram, sobretudo por suas declaraçóes de direitos. No limite, reconhece K. Marx (2010, p. 36), "Bauer exige [...] que o judeu renuncie ao judaísmo, que o homem em geral renuncie à religião, para tornar-se emancipado como cidadão". Nesses termos, caberia aos judeus, não a reivindicação de um privilégio, porém, a luta, enquanto cidadáos germânicos, pela emancipação política de seu país.

Com efeito, K. Marx apresenta essa formulação, mas questiona o tipo de emancipação buscado pelo autor em torno da polêmica sobre a questão judaica. Por ter como alvo apenas o "Estado cristão" vigente na Alemanha, B. Bauer deixa de criticar o "Estado enquanto tal", com antagonismos que lhe são próprios, e, por consequência, deixa de examinar a relação entre a emancipação política e a emancipação humana (MARX, 2010, p. 36). K. Marx concorda com B. Bauer a respeito dos limites da emancipaçáo religiosa que a comunidade judaica reivindica ao Estado alemáo. No entanto, tal crítica seria limitada, pois B. Bauer insiste apenas no escopo teológico da polêmica sobre o direito dos judeus. Para o autor de Sobre a Questâo Judaica, o conflito do homem adepto de uma religiáo particular com outros homens enquanto membros de uma comunidade política "[...] reduz-se ao cisma secular entre o Estado político e a sociedade civil.” (MARX, 2010, p. 36). Certamente, a emancipação política representa um progresso, mas ela não expressa a perfeita emancipação humana, porque não liberta o homem dos empecilhos seculares, pois resta aí um antagonismo que não supera os limites de um Estado teológico per se. Decerto, o "Estado democrático [...] não necessita da religião para chegar à sua completude política. Ele pode, antes, abstrair da religião, porque nele se realiza efetivamente em termos seculares o fundamento humano da religiáo." (MARX, 2010, p. 43). Ora, o "fundamento humano" que permanece no Estado democrático moderno reside em elementos ideológicos como a Declaração dos direitos do homem e dos cidadãos -, sobretudo a de 1793. Eis 
um elemento deixado no ponto cego da crítica de B. Bauer, sobre o qual K. Marx se detém.

Os direitos humanos seriam um dos principais resíduos do "fato enigmático" da dominação que permanece em movimentos históricos de transformaçóes sociais. No fundo, haveria, como que à sombra de tais direitos universais, um modelo de homem bem específico e, ainda, uma comunidade política pressuposta pela classe dominante em ascensão. K. Marx ironiza esse fato, ao sublinhar o "enigma" das reviravoltas ideológicas da dominação: um povo que começa a se libertar, a fundar uma comunidade política, acaba por proclamar solenemente a legitimidade do homem egoísta - assegurado em seu direito à liberdade, à propriedade e à segurança - "[...] no momento em que se faz constar na ordem do dia o sacrifício de todos os interesses da sociedade burguesa e em que o egoísmo precisa ser punido como crime." (MARX, 2010, p. 50). Afinal, o que o artigo 6 da Constituição de 1793 declara, quando afirma "A liberdade é o poder que pertence ao homem de fazer tudo quanto não prejudica os direitos do próximo" (diga-se de passagem, valendo-se de uma linguagem bem semelhante ao mandamento religioso "amai ao próximo como a ti mesmo")? Menos do que a constituição de uma comunidade política, esse artigo representa uma inversáo ideológica que impede a própria comunidade, pois “[...] o direito humano à liberdade não se baseia na vinculação do homem com os demais homens, mas, ao contrário, na separação entre um homem e outro. Trata-se do direito a essa separação, o direito do indivíduo limitado, limitado a si mesmo." (MARX, 2010, p. 48). No limite, o que está pressuposto nessa dialética é o modelo do indivíduo burguês, integrante de uma sociedade civil atomizada.

No entanto, uma declaração como essa poderia preservar a comunidade política na funçáo do cidadão, componente essencial dos direitos dos homens e dos cidadãos. Porém, não é essa a perspectiva adotada por K. Marx, pois o autor restringe esse termo - cidadão - ao campo do Estado político reduzido a um mero meio, pelo qual os interesses egoístas dos indivíduos burgueses se dinamizam. Decerto, com o advento do Estado moderno, o homem se liberta da limitação imposta por Estados teocráticos. Entretanto, esse novo Estado apenas se constitui como desvio. E, nesse sentido, o cidadão somente expressa as desventuras do homem que não se reconhece enquanto tal, senáo como membro de um Estado, de modo que o "fundamento humano da religiáo" se preserva novamente ali, onde aparentemente seria o momento de emancipação política: 
[...] o homem continua religiosamente condicionado, justamente porque ele só reconhece a si mesmo mediante um desvio, através de um meio. A religião é exatamente o reconhecimento do homem mediante um desvio, através de um mediador. O Estado é o mediador entre o homem e a liberdade do homem. Cristo é o mediador sobre o qual o homem descarrega toda a sua divindade, [...] assim como o Estado é o mediador para o qual ele transfere toda a sua impiedade, toda a sua desenvoltura humana. (MARX, 2010, p. 39).

No limite, mais uma vez, o que se preserva nos direitos dos homens e dos cidadãos é apenas o pressuposto da sociedade burguesa, a pintura final do quadro enigmático do Estado político, em que

[...] a cidadania, a comunidade politica, é rebaixada pelos emancipadores à condição de mero meio para a conservaçấo desses assim chamados direitos humanos [...] portanto, o cidadão é declarado como serviçal do homem egoísta; [...] quando vemos, por fim, que não o homem como cidadão, mas o homem como burguês é assumido como o homem propriamente dito $\mathrm{e}$ verdadeiro. (MARX, 2010, p. 39, grifo do autor).

Há somente um vínculo social efetivo que os direitos humanos da sociedade burguesa preservam: não é, como vimos, a liberdade, que mais separa do que aproxima os homens; tampouco a igualdade, que se revela abstrata, nos contratos entre partes diferentes. Trata-se da segurança, o fundamento dos vínculos entre indivíduos egoístas e temerosos uns em relação aos outros. Assim, o valor social máximo, conclui K. Marx, não é o bem público, mas o princípio de policiamento, o conceito supremo da sociedade burguesa, a garantia do egoísmo burguês, assegurado com a manutenção da paz social e da ordem pública, a despeito do conflito real que a permeia. Algo que W. Benjamin (1978, p. 94) recorda, quando afirma:

[O Homem] vive na comunidade política, onde se toma por um ser comum, e na sociedade civil, onde age simplesmente como um indivíduo privado, trata outros homens como meios, degrada-se diante do papel de simples meio e se torna o joguete de poderes alienados. O Estado político, em relação à sociedade civil, é exatamente tão espiritual quanto é o paraíso em relação à Terra [...]. Nesse Estado [...], o homem é o membro imaginário de uma soberania imaginária, privado de sua vida real e insuflado com uma universalidade irreal. 


\section{Claude Lefort: Direitos e democracia}

Diante dessas duas perspectivas críticas, é necessário perguntar: haveria saída para tais diagnósticos? Poderíamos, depois dessas críticas, ainda ler nas declaraçôes universais de direitos mais do que, por um lado, ineficácia política e risco de sediçáo no interior de governos benevolentes, e, por outro, ideologia ou sustentáculo irreal para um modo de vida desumano? Seriam simplesmente os chamados "direitos humanos" - para retomarmos a fórmula que usamos no início - demasiado abstratos, quando se pretendem reais, ou demasiado reais, quando se pretendem universais?

C. Lefort apresenta uma perspectiva inovadora para a discussão desse assunto. O filósofo insiste que é preciso considerar a ligação entre a democracia moderna e uma nova experiência social do direito e mostra que é preciso lançar máo de novos patamares teóricos que alcancem a envergadura dessa aventura inédita - dessa invenção - chamada democracia. O autor chega a realizar um chamamento aos pensadores, para que estes descubram na experiência democrática a necessidade de reabilitar a filosofia política. Assim, ao retomar as críticas inaugurais de E. Burke e K. Marx, C. Lefort recusa a visão dos predecessores e nos convida a descobrir o sentido da invenção democrática:

A condenação do naturalismo, tal como foi conduzida por pensadores tão díspares quanto Burke e Marx, invocando a realidade histórica, ignora paradoxalmente o que advém, como absolutamente novo, sob a fachada da afirmação do homem, da ilusão filosófica que suprime os homens "concretos" em proveito de um ser abstrato. Nenhum dos dois [Burke e Marx] percebe, com efeito, o que a ideia de direitos do homem recusa: a definição de um poder detentor do direito, a noçáo de uma legitimidade cujo fundamento está fora do alcance do homem, e, ao mesmo tempo, a representação de um mundo organizado no interior do qual os indivíduos encontram-se "naturalmente" classificados. Ambos, tomando como alvo a abstração do homem sem determinação, denunciam o universal fictício da Declaração Francesa, desconhecendo o que ela nos lega: a universalidade do princípio que traz o direito para a interrogação do direito. (LEFORT, 1991, p. 56).

Guardemos essa última fórmula: ela nos será bastante útil adiante. Antes, porém, de compreendermos exatamente o que se coloca aqui, devemos investigar o campo de discussão desenhado por C. Lefort, o qual permite essa articulação entre democracia e uma nova experiência do direito. $\mathrm{O}$ autor situa a democracia moderna entre duas formas historicamente determinadas do 
político: o Antigo Regime e o Estado totalitário, especialmente o figurado pelo stalinismo. No Antigo Regime, a sociedade se encontra suspensa numa imensa metáfora orgânica e teológica, a metáfora do corpo político do rei, identificação fantástica operada entre o social e o político, sob uma imagem, uma ideia e um nome, o nome do $U M$, corporificado, litúrgica e juridicamente, no governante, cuja vontade é a lei. No Antigo Regime, o político devora de certo modo o social, ao transformá-lo num órgão do corpo régio; o poder, a lei e o saber são personificados por essa unidade corpórea. Ora, é interessante notar que, no sistema totalitário, como as metáforas orgânicas do Gulag sugerem, novamente o social e o político são soldados num corpo único e indiferenciado - o do Partido-Estado, cujos órgãos e células constituem o tecido social - e cuja cabeça repóe o novo nome do UM: o Egocrata. $^{3}$

Diante desses fantasmas de unidade, de fato muito poderosos e assustadores, a invenção democrática é um acontecimento extraordinário, uma revolução que corre pelos séculos: ela é a instituição do político como nova instituição social pelo fenômeno exatamente oposto ao descrito acima. Tratase da desincorporação, pela perda da eficácia prática e simbólica da ideia, da imagem e do nome da unidade. Mas essa invenção não guarda apenas o aspecto da desincorporação, pois é o advento da divisão social reconhecida enquanto tal, da diferenciação interna entre o social e o político ou entre as esferas da existência social e a das instituiçôes políticas; em suma, a democracia moderna institui a alteridade em toda a espessura do social, instaurando a ideia dos direitos e diferenciando, pela primeira vez, o Poder, a Lei e o Saber, os quais ficam expostos aos conflitos das classes, dos grupos e dos individuos e, assim, impedidos

\footnotetext{
${ }^{3}$ É importante salientar que há uma diferença que separa o Antigo Regime do totalitarismo soviético: enquanto o primeiro preserva a referência do poder à transcendência, uma vez que a monarquia encontra seu fundamento na ordem divina, o segundo se configura como totalitário exatamente porque abole qualquer referência à exterioridade. $\mathrm{O}$ totalitarismo opera uma destruição da sociedade, à medida que esta é inteiramente absorvida pelo poder. $\mathrm{Na}$ monarquia, "[...] o poder estava incorporado na pessoa do príncipe. Isto não quer dizer que ele detinha um poder sem limites. O regime não era despótico. O príncipe era um mediador entre os homens e os deuses, ou então, sob o efeito da secularização e do laicismo da atividade política, um mediador entre os homens e as instâncias transcendentes figuradas pela Justiça soberana e pela Razão soberana. Submetido à lei e estando acima das leis, condensava em seu corpo, ao mesmo tempo mortal e imortal, os princípios de geraçáo e de ordem do reino. Seu poder indicava um polo incondicionado, extraprofano, ao mesmo tempo que inspirava, na sua pessoa, a garantia e a representação da unidade do reino. Ele via a si mesmo afigurar-se como um corpo, como uma unidade substancial, de tal maneira que a hierarquia de seus membros, a distinção entre as posiçôes e as ordens, parecia residir em um fundamento incondicionado." (LEFORT,1991, p. 32). Já no totalitarismo, "[...] o poder não aponta para um além do social: é um poder que reina como se não houvesse nada fora ele mesmo, como se fosse sem limites." (LEFORT, 1991, p. 28). Sobre essa discussão, cf. B. Flynn, 2008.
} 
de se petrificarem. Leitor acurado de Maquiavel e responsável pela vinculação do último à compreensão da democracia moderna, C. Lefort defende que a última desfaz as imagens da boa sociedade e do bom governo, da comunidade ideal transparente, virtuosa, sem conflitos, plenamente reconciliada consigo mesma. Comunidade que poderia ter de si mesma uma imagem que figuraria sua identidade e unidade.

Todavia, por que esse esfacelamento da imagem unitária e identitária da sociedade faz da democracia uma invenção do ponto de vista da relaçáo entre direito e poder? Porque, longe de ser a mera conservaçáo de direitos (ao contrário do que afirma K. Marx, a democracia moderna não pode ser definida apenas em função dos interesses dos indivíduos atomizados sob o modo de vida burguês), ela é criação ininterrupta de novos direitos, subversão contínua do estabelecido, dinâmica e reinstituição permanente do social e do político. Enquanto dinâmica de criação de direitos e, simultaneamente, enquanto reconhecimento, seja das divisóes internas à sociedade, seja das diferenças constitutivas do social e do político, a democracia abre um horizonte histórico que a desafia a sustentar a tarefa de reinventar-se constantemente, sob o risco de ser engolida pelo fantasma do $U M$.

C. Lefort nos convida a ir ainda mais longe. Descoberta e criação dos direitos, invenção contínua do social e do político através das divisôes e dos conflitos, a democracia moderna náo pode, escreve o autor, ser concebida propriamente como uma invençáo burguesa, pois ela nasceu da luta de classes, dos movimentos populares e operários, e sempre foi considerada pela burguesia um escândalo e um perigo maior do que o socialismo (segundo afirma, no prefácio de $A$ invenção democrática). Ora, é preciso distinguir a natureza específica de um poder, cujo exercício continua sempre na dependência da competição entre os partidos e do debate que se nutre das liberdades públicas e que as mantém. Poder que permanece sendo um lugar vazio, que não poderia ser definitivamente ocupado por um homem ou um grupo particular, capaz de encarná-lo dando-lhe uma imagem na qual a sociedade reconheceria sua própria identidade e unidade. Havemos de combater, ademais, a visão de que a democracia é apenas uma relação entre dois termos, o Estado e o indivíduo, para que então possamos reconhecer na instituiçấo dos direitos do homem e do cidadão os sinais da emergência de um novo tipo de legitimidade e de um espaço público do qual os indivíduos são tanto produtos quanto instigadores; com a condição de reconhecer, simultaneamente, que esse espaço só poderia ser 
devorado pelo Estado, a custo de uma violenta mutação que daria nascimento a uma nova forma de sociedade.

Vejamos como isso se manifesta, na interpretação da Declaração de 1791, proposta por C. Lefort, que reproduzimos a seguir (LEFORT, 1991, p. 47-48). Após ter proclamado o fim das distinçôes sociais (art. $1^{\circ}$ ), a Declaração enuncia, entre os direitos imprescritíveis, a resistência à opressão (art. 20); especifica-se, a seguir, que o princípio de toda soberania reside na nação. Nenhum grupo, nenhum indivíduo pode exercer autoridade a náo ser que emane expressamente da nação (art. $3^{\circ}$ ). Depois, fazendo da lei a expressão da vontade geral, deixa claro que "[...] todos os cidadáos têm o direito de concorrer pessoalmente ou através de seus representantes para a sua formação". C. Lefort observa que a articulação desses direitos é comandada pela ideia de direitos naturais: alude-se, nesse ponto, à sociedade política como se esta fosse uma "associação política" e póe-se como objetivo a conservação de direitos naturais. Porém, sob a fachada dessa linguagem, faz-se uso de noções, cujo sentido só é desvelado à vista das noções que baseavam a antiga ordem política, quer dizer, a ordem monárquica. Ora, é preciso observar que a soberania, a autoridade, a vontade geral e a lei são noções que se mostram aqui subtraídas de toda apropriação. Em que sentido? Afirma-se que a soberania reside na nação, mas esta, ninguém doravante pode encarnar; por isso, a autoridade só poderá ser exercida segundo regras que garantam que esta esteja legitimamente delegada; a vontade geral, por sua vez, é reconhecida na lei, cuja elaboração implica, contudo, a participação dos cidadãos.

Assim, esse conjunto de proposiçóes possui uma coerência interna, independente de qualquer referência a uma verdadeira natureza humana. Decerto, o eixo central desvelado por C. Lefort, o qual informa a tal coerência das declaraçôes, permite compreender a liberdade política como resistência à opressão. É verdade que os constituintes remetem a liberdade à natureza do homem. Porém, eles produzem essa formulação contra um regime onde o poder denega a seus súditos a faculdade de oporem-se àquilo que eles julgarem ilegítimo. Por isso, os direitos do homem visam a uma reivindicação de liberdade que póe em ruínas a representação de um poder situado acima da sociedade, e que disporia de uma legitimidade absoluta, poder que estaria incorporado no monarca ou na instituição monárquica. Chegamos, pois, ao cerne da formulação que fizemos acima ${ }^{4}$ : a Declaração dos direitos marca a desintrincação do direito e do poder. Para C. Lefort, o direito e o poder

\footnotetext{
${ }^{4}$ Trata-se da universalidade do princípio que traz o direito para a interrogação do Direito.
} 
não mais se condensam no mesmo polo. Todavia, não só isso. Para que seja legítimo, o poder deve doravante ser conforme ao direito e, deste, ele não detém o princípio (LEFORT, 1991, p. 48).

Isso nos leva a outro fenômeno: a afirmação do direito faz recusar a onipotência do poder. O Estado deve garantir, sim, a propriedade, a segurança e a liberdade dos cidadáos. Entretanto, a ameaça de opressão coloca outro problema. Ela culmina na hipótese de um golpe à soberania da nação. Assim, não é ao Estado que se apela para a garantia desse direito de resistência; é do próprio interesse dos cidadãos dele se encarregarem (surgem aqui ecos do Maquiavel republicano, isto é, daquele para quem a classe negativa, cujo humor dominante é o de recusar a dominação, aparecia como a mais apta para salvaguardar a liberdade de todos, no interior da cidade). Esse desenvolvimento evidencia, portanto, que o naturalismo das declaraçóes é apenas "de fachada", porque se trata de compreender, ao contrário, o fenômeno da dessubstancialização das instâncias do poder e do direito e, ademais, a separação dessas duas dimensôes.

Falta, contudo, responder à afirmação de que os direitos têm apenas referência no indivíduo. É preciso sublinhar que, na verdade, eles têm um alcance político. Vimos que K. Marx persegue todos os sinais de individualismo e de naturalismo nas Declaraçôes, a fim de lhes atribuir uma função ideológica: já que, sob a máscara de direitos universais, eles seriam apenas a marca da atomização do homem, a justificativa do egoísmo burguês. Assim procedendo, assevera C. Lefort, K. Marx torna evidente um traço do pensamento da época, mas continua movendo-se no terreno da ideologia (a qual pretende extirpar), ao ignorar a subversão das relaçôes sociais e políticas encobertas sob a representação burguesa dos direitos. Absorvido por essa representação, K. Marx está persuadido de que ela corresponde à realidade efetiva da sociedade civil. Bastaria rasgar o véu do direito para ver a figura trivial dessa sociedade atravessada pela violência e pela opressáo. Porém, os direitos do homem não são um véu, pois, longe de terem por função mascarar a dissolução dos liames sociais, eles atestam e, ao mesmo tempo, suscitam uma nova rede de relaçóes entre os homens.

Abordemos dois pontos fundamentais para compreender esse aspecto: a liberdade de opinião e a segurança. Segundo C. Lefort, a liberdade de opiniấo náo faz dela uma propriedade privada, concebida a partir do modelo de propriedade dos bens materiais. Trata-se de uma liberdade de relaçóes. A cada qual é dada a possibilidade de se dirigir aos outros, e de ouvi-los: eis que 
um espaço simbólico se institui, sem fronteiras definidas, subtraído a toda autoridade que pretenda regê-lo ou decidir em seu lugar sobre o que é ou não pensável, sobre o que é ou não dizível. A fala enquanto tal - e o pensamento - mostra-se, nesse aspecto, independente da sanção de qualquer indivíduo particular, quer dizer, ela não é propriedade de ninguém. Do mesmo modo, as garantias de segurança, nas quais $\mathrm{K}$. Marx encontra a mais abominável expressão da sociedade civil, a transcrição de um conceito de polícia em proveito da proteçáo do burguês, demonstram, ao contrário, que a justiça está desligada do poder, que seu impulso está em si mesma, pois, ao abrigar o indivíduo contra a arbitrariedade do poder, faz disso um símbolo da liberdade que funda a existência da nação.

$\mathrm{O}$ mais importante, não obstante, é combater a tese principal de $\mathrm{K}$. Marx: a democracia triunfou, instituindo uma separação entre a sociedade civil, lugar das opiniōes sem poder, e o Estado laico liberal, lugar do poder sem opinióes. Em prol desse sistema, o Estado sempre cresceria em força, agora, sob a fachada da neutralidade, e a sociedade civil se enfraqueceria sem cessar, não deixando de ser um teatro de opinióes que, por serem individuais, se neutralizariam constantemente. Essa tese ignora o acontecimento que determina a formação de um poder neutro e, ao mesmo tempo, a formaçáo de opiniōes livres; a desaparição do fundamento sobrenatural ou natural, no qual residia essa autoridade e ao qual ela podia apelar, de sorte a reivindicar uma legitimidade incontestável, um conhecimento dos fins últimos da sociedade e da conduta dos homens, para os quais eram atribuídos lugar e função, por assim dizer, naturais, dentro do Antigo Regime.

A originalidade política da democracia é assim designada neste duplo fenômeno: um poder destinado a permanecer em busca de seu fundamento e uma sociedade que acolhe o conflito de opinióes e o debate de direitos, porque se dissolveram os marcos de referência da certeza que permitiam aos homens, no Antigo Regime, situarem-se de uma maneira fixa:

Duplo fenômeno, sinal de uma só mutação: o poder deve doravante obter sua legitimidade enraizando-se nas opinióes, ou ao menos sem se entrincheirar da competiçáo entre partidos. Ora, a competição entre partidos procede do exercício das liberdades civis e ao mesmo tempo o mantém - faz mais: ativa-o. É verdade que o Estado parece neutro, sem opiniôes, ou acima das opiniôes; porém, as transformaçôes que conheceu [...] surgiram da evoluçáo da opinião pública, ou foram produzidas em função desta, inclusive essa separação que, separando-o da Igreja, constituino Estado laico. (LEFORT, 1991, p. 52). 
Mas não se trata simplesmente de confundir opiniáo e direito. C. Lefort reconhece um espaço público, sempre em gestação, cuja existência embaralha as fronteiras aceitas entre o político e o não político. E aqui surge uma correção de enorme importância: desse ponto de vista, a distinção entre a sociedade civil e o Estado não dá conta inteiramente do que advém com a formação da democracia. Ela não pode ser compreendida como uma pura divisão, à qual K. Marx se referia. Opondo ao modelo da sociedade feudal, onde as relaçôes políticas estariam imbricadas às relaçóes socioeconômicas, o modelo da sociedade burguesa, onde a esfera do público, tendendo a coincidir com a esfera do Estado, estaria cindida de uma esfera propriamente civil, K. Marx esquecia que o Antigo Regime tinha largamente destruído o sistema feudal e que o Estado já detinha o princípio de autoridade, antes de estar em condiçóes de fazer com que todas as instâncias agissem de maneira eficaz. Decerto, o que K. Marx nomeia sociedade burguesa distingue-se pelo fortalecimento da potência estatal, contudo, não menos pelo sistema representativo, isto é, pelo dever que o governo guarda de emanar do conjunto social. Esses dois traços não são dissociáveis, ainda que se possa enfatizar um ou outro.

Ora, por que é importante tratar da especificidade da representação? Porque corremos o risco de apagar o alcance de uma constituição nos termos da qual a autoridade pública é estabelecida, exercida e periodicamente renovada, em decorrência de uma competição política, uma vez que, através desta, os conflitos se manifestam na vida social. A eficácia da representação encontra-se contrariada pela permanência de um aparelho de Estado, cuja complexidade não deixa de recrudescer; porém, é preciso resistir a esse movimento. Quaisquer que sejam a extensão e a complexidade desse aparelho, vemos o quanto é impotente para unificar-se, à medida que cada um de seus setores se acha subordinado às pressóes das categorias particulares de empregados ou de atores sociais que defendem a autonomia de sua esfera de competência, e à medida que a lógica da gestão, que os funcionários procuram fazer prevalecer, enfrenta a lógica da representação imposta às autoridades eleitas. Em suma, assim como o Estado não pode fechar-se sobre si mesmo, para tornar-se o grande órgão que comanda todos os movimentos do corpo social, também os detentores da autoridade política permanecem obrigados a pôr em causa, periodicamente, o princípio de conduta dos assuntos públicos.

Com esse passo, perdemos de vista a crítica aos direitos humanos? De maneira alguma. Como salienta C. Lefort, qualquer reivindicação precisa se 
beneficiar do acordo ao menos tácito de uma significativa fração da opinião pública, deve se inscrever no espaço público:

[...] uma das condiçôes de êxito da reivindicação reside na convicção partilhada de que o novo direito está conforme à exigência de liberdade que atestam os direitos já em vigor. Assim é que, no século XIX, o direito de associaçáo dos trabalhadores ou direito de greve, mesmo resultando de uma mudança nas relaçóes de força, foram reconhecidos, exatamente junto àqueles que não eram os instigadores, como uma extensão legítima da liberdade de expressão ou da resistência à opressão. (LEFORT, 1991, p. 54).

Noutros termos, os novos direitos como que se incorporam retrospectivamente ao que foi considerado constitutivo das liberdades públicas.

K. Marx não compreendeu onde residia o verdadeiro "enigma” da democracia, o qual envolve essa nova configuraçáo dos direitos e se define pelo direito a ter direitos:

[...] a concepçáo naturalista do direito mascarou o extraordinário acontecimento que constituía uma declaração que era uma autodeclaração, isto é, uma declaraçáo na qual os homens, através de seus representantes, mostravam-se simultaneamente como sujeitos e como objetos da enunciaçáo, na qual, a um tempo, nomeavam o homem em cada um, "falavam-se" entre si, compareciam uns frente aos outros, e, assim procedendo, erigiam-se em testemunhas, em juízes uns dos outros. (LEFORT, 1991, p. 56).

Nem inúteis, nem perigosas, nem pura ideologia de uma sociedade atomizada e desumana: as declaraçóes dos direitos do homem e do cidadáo abrem, segundo C. Lefort, um verdadeiro horizonte histórico, que não se confunde com uma teleologia da história. É preciso reinventar-se, estar em constante processo de instituição, o que nos leva a realizar uma observação final. O conflito no interior da sociedade e o quiasma entre esta e o Estado, tal como o descrevemos aqui, mantêm como referência as noçóes de processo e de história. Quer dizer, C. Lefort não pensa o político enquanto ação que suspende o tempo, ou que se dá fora do tempo. Pelo contrário, o autor nos convida a pensar a democracia representativa enquanto um campo aberto a processos reivindicatórios, cuja dinâmica possibilita a instituição de novos direitos, tendo em vista os que já foram historicamente reconhecidos e assegurados. Por isso, através dele, podemos questionar o que de fato torna a representação 
democrática. Para responder a essa pergunta, é preciso compreender a temporalidade envolvida no processo de representação e o que a torna apta para dinamizar a luta por direitos, ao contrário, por exemplo, da democracia direta. Segundo a observação precisa de uma autora contemporânea:

$\mathrm{O}$ voto direto (ou, nas palavras de Condorcet, a "democracia imediata") não cria um processo de opinióes e não permite que elas se baseiem em uma continuidade histórica, pois faz de cada voto um evento absoluto e, da política, uma série única e discreta de decisôes (soberania pontuada). Mas quando a política é programada de acordo com os termos eleitorais e as políticas incorporadas pelos candidatos, as opiniōes compóem uma narrativa que vincula os eleitores através do tempo e do espaço e faz das causas ideológicas uma representaçáo de toda a sociedade e de seus problemas [...] a democracia representativa revela o trabalho "miraculoso" das opinióes e narrativas ideológicas de uma forma que a democracia direta não é capaz, pois ela nos compele a transcender o ato de votar, num esforço de se reavaliar repetidamente a correlação entre o peso das ideias e o peso dos votos (na preservaçáo, obtençáo ou aumento do consentimento). $\mathrm{Na}$ democracia direta, todo voto é como um novo começo (ou uma resolução final). (URBINATI, 2006, p. 211-212).

Não se trata, portanto, de instituir juízos finais ou de cegar-se para a natureza do político. Pelo contrário, trata-se de continuar a produzir diferenciações internas no seio de um processo que permitiu a reinvenção da vida comum, num terreno permeado pela dinâmica democrática do conflito.

RAMOS, Silvana de Souza. Claude Lefort: Democracy and the fight for rights. Trans/form/ ação, Marília, v. 39, n. 2, p. 217-234, Abr./Jun., 2016.

\footnotetext{
ABSTRACT: Having as the central theme the debate about the notion of human and citizen rights and the effectiveness of these in relation to the political struggle for new rights, this article investigates the innovative character of modern democracy. In his approach to the subject, C. Lefort argues three theses: the idea that the defense of universal human rights represents a danger to vigorous politics in benevolent States; the thesis which says that these rights would be the most complete expression of the ideology of bourgeois individualism and correspond to empty formalities whose meaning would be simply to hide social violence and enshrine privileges; and, finally, the argument that democratic institutions would aim to only reproduce the property relations and forces existing in capitalism and not allow the expression of social contradictions or their resolution in the field of politics. The article reviews the political philosophy proposed by Lefort, which emphasizes the unprecedented nature of
} 
representative democracy, and then explains the historical perspective of struggle for rights opened by the democratic invention.

KEYWORDS: Claude Lefort, Karl Marx, Edmund Burke, democracy, rights, politics.

\section{REFERÊNCIAS}

BENJAMIN, W. Critique of violence. In: . Reflections. Tradução de E. Jephcott. New York: Schocken Books, 1978. p. 277-300.

BURKE, E. Reflexóes da filosofia em França. Tradução de R. A. Faria. Brasília, DF: Ed. UnB, 1977.

FLYNN, B. Lefort y lo político. Tradução de Gabriel Merleino. Buenos Aires: Prometeo Libros, 2008.

LEFORT, C. Le travail de l'Euvre Maquiavel. Paris: Gallimard, 1972.

- Pensando o político: ensaios sobre democracia, revoluçáo e liberdade. Tradução de Eliana M. Souza. Rio de Janeiro: Paz e Terra, 1991.

- Desafios da escrita política. Tradução de Eliana de M. Souza. São Paulo: Discurso Editorial, 1999.

- A invençâo democrática: os limites da dominação totalitária. Tradução de Isabel Loureiro e Maria L. Loureiro. Apresentação de Marilena Chauí. Belo Horizonte: Autêntica, 2011.

MARX, K. Sobre a questão judaica. Tradução de Nélio Schneider. São Paulo: Boitempo, 2010.

STRAUSS, L. Natural rights and history. Chicago: University of Chicago Press, 1965.

URBINATI, N. O que torna a representação democrática? Lua Nova, São Paulo, n. 67, p. $191-228,2006$.

Recebido em 22/12/2015

Aceito em 08/03/2016 
RAMOS, S. S. 